\title{
On Characteristics of the Plots in Katherine Mansfield's Short Stories
}

\author{
Aijing Zhang \\ College of Teacher Education, Nanjing Normal University, Nanjing, China
}

\section{Email address:}

2406231477@qq.com

\section{To cite this article:}

Aijing Zhang. On Characteristics of the Plots in Katherine Mansfield's Short Stories. International Journal of Secondary Education. Vol. 6, No. 2, 2018, pp. 33-36. doi: 10.11648/j.ijsedu.20180602.12

Received: May 9, 2018; Accepted: May 30, 2018; Published: June 18, 2018

\begin{abstract}
Katherine Mansfield is a legend in the history of the modern British literature for her implicit writing style. She was regarded as one of the most prominent innovators and pioneers of English short stories. Most of her works are carefully organized in the structure, concentrating on creating the inner world of the characters instead of a clear beginning or tense conflicts, so as to invite readers to explore the subtle changes of the characters' psychological world. There have been a large number of studies on the subjects like feminism, modernism, dream disillusionment, narrative style and rhetorical devices of her short stories, but only a few talk about the plot structure because there seems to be no clear boundaries between the beginning and the development, and the development and the ending. This thesis intends to and generalize the structural features of her short stories, including The Garden Party, Bliss, A Cup of Tea, An Ideal Family and so on, mainly from the following three aspects: the stream of consciousness, shifts of occasions, and the function of objects. It is found that there are some regularities in the settings of the beginnings and endings in her stories. And from the analysis of her short stories, it may help us learn more about what is artistic beauty and about how to design the story-telling process.
\end{abstract}

Keywords: Katherine Mansfield, Stream of Consciousness, Shifts of Occasions, Function of Objects

\section{Introduction}

\subsection{The Short Stories}

Most of Katherine Mansfield's short stories have simple plots and concise language, which make the stories easy to understand, but difficult to appreciate the themes. [1] The following three short stories can be taken to illustrate this.

The Garden Party tells about a young girl named Laura Sheridan. She was born in a rich family. One day they have a party in their garden and almost everything has prepared. It is at that time that Laura hears their poor neighbor is knocked to death, so she thinks they have to stop the party. However, her sister and mother don't think so, and they decide to continue to hold the party. Laura is confused and when the party finishes, she is asked to visit the poor family. She feels quite uneasy in the process and is dubious about life and happiness.

While Bliss is about a young woman called Bertha Young, who always feels happy and satisfied about her life. She has deep and unutterable bliss in her heart. On that day, she holds a party at home and invites her good friends who she thinks are nice and perfect. However, at the end of the party when her friends are leaving, she finds the affair between her mysterious friend Miss Fulton and her enthusiastic husband Harry. She is confused and runs over to the long windows to see the pear tree that she shared with Miss Fulton not long ago. [2]

Rosemary Fell in A Cup of Tea is a wealthy, married woman. When she finishes shopping in Curzon Street, she meets up with a poor girl called Herself Miss Smith. Miss Smith begs her for the money for a cup of tea, however Rosemary just takes her to her opulent mansion and wants to show her that "rich people did have hearts." Then, Rosemary's husband, Philip, comes back home and disapproves of her request to keep Miss Smith. When Rosemary rejects to dismiss Miss Smith, Philip comes up with another idea that he tells His wife that he thinks Miss Smith is lovely and pretty. And Rosemary picks up three five-pound notes and sends Miss Smith away out of her jealousy, she the comes to her husband and asks him whether she is pretty. [3]

\subsection{Previous Research}

Before 1930, comments about Katherine Mansfield's short 
stories mostly came from writers and critics, who held that her early works were not so successful, either for the similar characters or for her shallow understanding of the cultural background of England. For example, she published Prelude in 1917, a kind of work which largely reformed the English short stories. It has no set structure and the narrative shifts again and again in it. It was not until Bliss and The Daughters of the Late Colonel that won lots of good reputation for her. Research on her short stories has begun to popularize since 1930. J. F. Kobler took her as a born romantic writer in his Katherine Mansfield. [4] David Daiches, a Scottish literary critic and literary historian, thought of Mansfield as an innovator in his work New Literary Values, pointing out that her stories had broken away from the traditional reliance of novels on plots and raised the importance of fiction forms. [5] Up to now, the research on Mansfield's short stories has focused on three aspects. The first is research on her life experience, letters, literary activities and some other autobiographic things. The second is on the analysis of her works associated with psychology, sociology, history and aesthetics. The last is about the comments from the perspective of feminism.

Research in New Zealand keeps going and thriving. She is considered as one of the most influential and significant ethnic writers in New Zealand. But it has not prevailed until the 1980s because of its lagging cultural development. During this time, Scholars and Academics like Antony Alpers, Ian A. Gordon, a professor concentrated on stories set in New Zealand and Gillian Boddy have made great contributions to the research. Antony Alpers published the most acknowledged biography of Mansfield---- The Life of Katherine Mansfield in 1980. [6] And Ian A. Gordon put a lot of emphasis on the eternal theme of New Zealand and the rich rural color in Mansfield's stories. [7] Compared with research in England, research in New Zealand pays more attention to Mansfield's complex of countryside and hometown, and the cultural and artistic influence in her works.

\section{The Development of the Plots}

Different writers have different writing styles. For Katherine Mansfield, her design of plot structure deserves exploration because there seems to be no clear boundaries between the beginning, the developmental plot, and the ending. The three aspects stream of consciousness, shifts of occasions and function objects can help us understand the characteristics of her plot design.

\subsection{Stream of Consciousness}

"Stream of consciousness, in literature, is a technique that records the multifarious thoughts and feelings of a character without regard to logical argument or narrative sequence. The writer attempts by the stream of consciousness to reflect all the forces, external and internal, influencing the psychology of a character at a single moment." [8] Actually, there are two techniques for representing consciousness. One is interior monologue, and the other is free indirect style. And in
Mansfield's short stories, the two techniques are widely employed.

In A Cup of Tea, it is a little difficult for the reader to see the personality of Rosemary and understand her actions in the story without the employment of stream of consciousness. She is a married woman, rich, beautiful and fashionable. The plot begins when Miss. Smith asks her for some money for a cup of tea, then Rosemary plans to take Miss. Smith to her house and keeps her, for she wants to have an adventure in the books she read. She thinks in her own mind that she does good to the poor girl, but she pays no attention to her true demands, just to make her more nervous and frightened. And when her husband, Philip comes back and tells her that he thinks Miss. Smith is rather pretty, Rosemary eats her promise to take Miss. Smith and sends her out with three-pound notes in the end out of her envy and jealousness.

Again in The Garden Party, the main character Laura begins thinking when she is asked to arrange the marquee-she thinks she can do it much better than anyone else. When she meets the workers, she is nervous for her care about the bread-and-butter, and feels the workers are impressive and friendly: "How very nice workmen were! And what a beautiful morning! She mustn't mention the morning; she must be business-like." After she answers the phone from Kitty and sits down, she has a wonderful experience of the silence, as she wonders whether the air is always so nice. When she finds the "a wide, shallow tray full of pots of pink lilies," she "felt they were in her fingers, on her lips, growing in her breast." From all this, the inner activities are not so frequent, since Laura is always having vocal communication with other people, and it can be inferred that Laura is a quite innocent, lively and lovely young girl. But the conflict come when Laura hears about the death of their neighbor and to avoid being alienated from her siblings and mother, she chooses not to tell everything to others, and the inner struggle starts. She feels there is something wrong at her heart, but she cannot confirm it. The reality is different from her gentility and education, so she gets lost. That is the climax of consciousness. Then she is asked to send something to comfort her neighbor, she feels ashamed and sorry for her splendid dressing, afraid and nervous of the environment of the neighbor's living place. The self-doubt in her mind does not stop until she sees how peaceful and happy the dead man looks, but it is this finding that makes her more distressing and woeful about the reality of life. She has nobody to tell because she already knows that nobody can understand her, therefore she has to bear it in mind. The interior monologue appears frequently from the climax of the story to the end, showing the solitude, inner fight and disillusionment of the main character.

As is shown above, both the interior monologue, and the free indirect style can contribute to readers' better understanding of the character's personalities and their upcoming choice, behaviors and speech, or even the characters' fate, which will definitely help reveal the themes of the story.

\subsection{Shifts of Occasions}

In Mansfield's short stories, the occasions are always 
changing, from one place or time to another. It is by this frequent shifts of occasions that the characters' mental activities and plots develop. When the plots in the short stories are not apparent and distinct, the shifts can show plots and indicate subtle changes in the stories.

Take an Ideal Family as an example, when the main character, the old Mr. Neave went bake home from his office on foot, there are various occasions, and Mr. Neave has different feelings and thoughts in his mind under different occasions. When "he pressed through the swing door and descended the three broad steps to the pavement", he first felt that he was too old to experience spring. He looks back his day and finds that his handsome son Harold "hadn't come back from lunch until close on four," therefore he is worried about his business. Then he stops "under a group of ancient cabbage palms outside the Government buildings", remembering what his children complained to him about his hard work. As he climbs the hill, he cannot help smiling bitterly for he wonders what life would be like without his hard work and thinking back that his guests always tell him that he has an ideal family. It is when he reaches his house that he begins imagining about the flowers, the house and the marks on the drive. He stands in the dusty hall, hearing the ordinary talks between his wife and children in the music room. His wife Charlotte tries to talk to him but she is too busy dealing with the children, so $\mathrm{Mr}$. Neave is forgotten by them, and gradually sinks into dream. $\mathrm{He}$ is very old and tired, but Charlotte tells him there is going to have friends at home, and he has to go to dressing-room, in which he lies down and dreams about his guests again telling him he has an ideal family. When he starts up, he finds he is alone and it is dark outside, only the passion-vine seems to understand him. It is shown in the shits of occasions from the swing door to his dressing-room, he is always thinking and imagining, because nobody keeps his accompany and understands his sorrow, fatigue and loneliness. And what's more, the shifts of occasions can play the role of plot since plot in this short story is ambiguous.

To sum up, the frequent shifts of occasions in Mansfield's stories are not mere occasion changing. The shifts are mostly carefully designed to show the subtle changes in character s' feelings and thoughts in their mind, and thus pushing the plot to develop.

\subsection{Function of Objects}

Objects in the stories are as important as characters. They can help push the development of plots. And in Mansfield's short stories, there are at least one object in each short story that plays a very important role either in implying the psychological activities of the main character or in revealing the themes of the story. [9]

As in The Garden Party, Laura first appears with a piece of bread-and-butter holding in her hand, making her a little awkward when she meets the workmen, because she thinks the bread makes her look informal and immature. However, she finds that the workmen are very kind and friendly, and she then takes "a big bite of her bread-and-butter," just to prove how happy and at home she feels, and how she despises stupid conventions. The bread-and-butter is used to show the innocence and liveliness of Laura. Later in the plot when Laura faces the conflicts of views on the death between her mother and siblings and herself, the "new hat" turns up. When Mr. Sheridan cannot persuade Laura to believe in her, she is impatient and suddenly changes the topic and shows the beauty of the hat to Laura. Laura stays alone in her bedroom, looking at herself from the mirror. She finds that she is extraordinary pretty with the new hat, and so she finally decides to reconsider the neighbor's death after the garden party. The hat shows the wrong family education of the upper class at that time, forcing the children to obey rather than explaining and directing them. In fact, Mr. Sheridan cannot persuade because it is likely that she herself does not understand, either. When the party begins, Laura is constantly praised by the guests who are addicted to her for her new hat. She is a little lost in the fancy and luxury. But the dream breaks the moment she is on the way to her neighbor's. It is the hat that makes her ashamed and depressed, showing the disrespect to the dead and the poor as she wakes up from her illusion. The hat in the plot largely represents Laura's different feelings and psychological conflicts, making her uneasy and finally leading her to reality. [10]

Generally speaking, objects in Mansfield's short stories play an essential role in revealing the characters' mental activities. To show the complex thoughts in the character's mind, the author uses stream of consciousness, but to make readers understand the character's feeling correctly, the author presents different objects as a hint. Meanwhile, the objects which represent thoughts and feelings can also help readers make inferences of the themes.

\section{Conclusion}

To put it in a nutshell, there are three important elements to develop the plots in Katherine Mansfield's short stories. The first is the stream of consciousness; the second is the shifts of occasions; the last is the objects concerned with the characters. The stream of consciousness contributes to readers' better understanding of the character's personalities and their later actions. The shifts of occasions are designed to show the subtle changes in characters' feelings and thoughts. And objects always play an essential role in revealing the characters' mental activities. All in all, they are related with each other and push the plot together: the objects and consciousness rely on the occasions, while they lead to the shifts of occasions as well. All of them are necessary for an accurate inference of the themes.

\section{References}

[1] Shimei Huang. Light of Bliss; Disillusion of Hopes----On the Illusion of Blissful Feelings in Mansfield's Short Story Bliss. Overseas English, 2013.

[2] Katherine Mansfield. Bliss and Other Stories. Createspace Independent Pub, 2016. 
[3] Katherine Mansfield. The Collected Stories of Katherine Mansfield. Penguin Group, 2007.

[4] Kobler, J. F. Katherine Mansfield: A Study of the Short Fiction. Twayne Publishers, 1990.

[5] David Daiches. The Art of Katherine Mansfield. New Literary Values: Studies in Modem Literature, 1936.

[6] Alpers, A. The Life of Katherine Mansfield. Oxford Lives, 1980.

[7] Ian A. Gordon. Undiscovered Country: The New Zealand Stories of Katherine Mansfield. Longman Group, 1974.
[8] William H. Harris and Judith S. Levey. The New Columbia Encyclopedia: Fourth Edition. New York and London. Columbia University Press, 1975.

[9] Jianing Chen. The Artistic Features of Mansfield's Short Stories. Journal of Capital Normal University, 1985.

[10] Liyun Zhou. A Psychological Analysis of Laura's Personality in Katherine Mansfield's The Garden Party. Overseas English, 2015. 